DOI: https://doi.org/10.47405/mjssh.v5i1.346

\begin{tabular}{|c|c|}
\hline 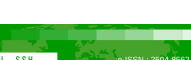 & Malaysian Journal of Social Sciences and Humanities (MJSSH) \\
\hline Malaysian Journal of & Volume 5, Issue 1, January 2020 \\
\hline (MJ - SSH) & e-ISSN : 2504-8562 \\
\hline & $\begin{array}{l}\text { Journal home page: } \\
\text { www.msocialsciences.com }\end{array}$ \\
\hline
\end{tabular}

\title{
The Struggle of Orang Asli in Education: Quality of Education
}

\author{
Aidil Fitri Bin Sawalludin', Charmaine Lim Jia Min', Mohamad Izzuan Mohd Ishar ${ }^{2}$ \\ 1School of Electrical Engineering, Faculty of Engineering, Universiti Teknologi Malaysia (UTM) \\ ${ }^{1}$ School of Education, Faculty of Social Sciences and Humanities, Universiti Teknologi Malaysia (UTM) \\ Correspondence: Charmaine Lim Jia Min (jiamin0408520@gmail.com)
}

\begin{abstract}
This article is a case study on the education of Orang Asli in Malaysia. Indigenous people or "orang asli" are the oldest inhabitants of Peninsular Malaysia but they are the minority among the total population in Malaysia. A study showed that around 50 percent of the students from the Orang Asli community do not further their study in secondary school after finishing their primary school and only 30 percent of students of Orang Asli finish their secondary school, which is less than half of the national average. The statistics of the education progress of Orang Asli are quite worrisome for a lot of parties especially the government and there are a lot of factors that contribute to those, not goodlooking results. In order to improve the quality of education, studies on the challenges faced by the Orang Asli are a must. There are a lot of factors causing that specific problem. One of the factors is would be the awareness amongst the Orang Asli community towards education and another factor is would be the Orang Asli accessibility to their nearest education institution. In a nutshell, the Orang Asli are the minority communities that had been marginalized for decades and to achieve the aim to reduce poverty and uplift quality of life them, education is the main key to success.
\end{abstract}

Keywords: indigenous people, education, accessibility, quality of life

\section{Introduction}

Educate, is a derived word from the Latin word of "educat" which means led out. Education is by definition is the process of receiving or giving systematic instruction, especially at a school or university. Education is becoming an essential need of the people who are trying to achieve a better and easier life during their lifetime in this world. Malaysia, a Southeast Asia country that is placed at the Malay Peninsula and Borneo Island, always prioritize the education development of her people. This is shown when the Malaysian Government agreed to allocate the funding of RM 64.1 Billion towards the education sector in the recent 2020 Budget Speech at the Malaysia Parliament by The Honourable Tuan Lim Guan Eng, Minister of Finance. Although the education sector received well attention and a large sum of funding by our government, the progress of education amongst the Orang Asli community, the Indigenous people in the Malay Peninsula is not aligned and even far behind with the progress of other ethnic races such as the Malays, the Chinese and the Indians.

Indigenous people or "orang asli" are the oldest inhabitants of Peninsular Malaysia but they are the minority among the total population in Malaysia. They comprise diverse groups of 18 indigenous ethnic tribes, distinguished by their respective ethnic languages and social-cultural identities (Lye, 2011; Tarmiji, Fujimaki \& Norhasimah, 2013; JAKOA, 2015). The Orang Asli population grew from 
54,033 in 1969 to 92,529 in 1994 , at a rate of almost 2.3 percent per year (Department of Social Welfare, 1997) and it is estimated that there are more than 370 million indigenous people spread through 70 countries worldwide (Jaura, 2010). Their social and economic position situates them among the disadvantaged minorities, the majority living beneath the poverty line (Mohd Asri, 2012) and marginalized (Johari \& Nazri, 2007; Tarmiji, Fujimaki \& Norhasimah, 2013).

A study shown that around 50 percent of the students from Orang Asli community do not further their study in secondary school after finishing their primary school (Fatan Hamamah, 2008), as much as 39.1 percent of students of Orang Asli finish their primary school but do not register in Form 1 (JHEOA, 2008) and only 30 percent students of Orang Asli finish their secondary school, which is less than half of the national average (Kementerian Pendidikan Malaysia, 2012). The rate of dropout for students from the Orang Asli community among the students in secondary school is higher compared to primary school (Zainal Abidin, 2008). Fieldwork research also found that the passing rate among the Orang Asli students in the primary school exams is quite low, around the average of 11.1 percent and 2.2 percent for SK Pos Pulat and SK Pos Brooke respectively in 5 years, which is from the year of 2004 until 2008. The statistics of the education progress of Orang Asli are quite worrisome for a lot of parties especially the government and there are a lot of factors that contribute to those, not goodlooking results.

\section{Objective}

To identify the quality of education of Indigenous People (Orang Asli) in Malaysia.

\section{The Struggle in Education}

In a 2016 study conducted by Mazzlida M.D \& Ruhizan M.Y., one of the factors that lead to the worse performance of Orang Asli in the education sector is the influence of the parents themselves. Most of the Orang Asli community especially the parents do not aware of the importance of education in improving theirs and their children's lives. This is because most of them have not received a formal education at all and only a small amount of people do further their studies until primary school but do not finish it. A lot of them drop out of school earlier and then got married to their beloved and go to work for their family at a very young age. With this kind of situation that has happened upon them, these parents are acknowledged as ill-educated people who cannot give good examples to their children about the importance of education itself.

The parents' attitudes towards their children also play the main role here in developing their children's progress in education. It is reported that most of the parents there do not give their attention to their children's education because they do not have the time. They even not bothered to scold or nag their children for playing truant during their school time or even ask about their children's homework or even gift them proper reading materials to them because they themselves are not well familiar with education itself. The negligence and ill-experience in the education of the parents towards their children have contributed to the bad outcome of Orang Asli in the education sector.

On the other hand, based on research in 2014 by Wan Afizi W.H., Shaharuddin A. \& Noraziah A., it is shown that the accessibility for the children of Orang Asli to go to school is also another major factor here. For general knowledge, it is known that most of the Orang Asli settlements are usually located in rural areas and they are very far with well-developed towns and cities which enjoy great infrastructures and facilities. The distance from the home of the children of Orang Asli to the nearest school is quite far, even the connectivity between them such as paved roads and bridges are not well established and public transportation such as buses cannot be provided because of its bad connectivity. This situation has made the travel distance to go to school from their home is a very time consuming and exhausting feeling indeed for the children which demotivates them to continue further their studies well and fine. 


\section{The Quality of Education}

Various aspect has been covered by the quality of life for all individuals from all walks of life and these include the quality of education which is very significant as it is cited by Nelson Mandela, "Education is the most powerful weapon which you can use to change the world." However, it is proven by numerous local and foreign investigators that the quality of education of indigenous people is still at a low level and is still very far behind as compared to the mainstream society and this is a critical problem. This is because the indigenous people have so much in common with other neglected parts of societies. This can be proven by the statement that they did not represent or participate in any political activities and the access to social services is lacking. Discrimination, economic marginalization, and poverty happened among these groups of people and thus, the indigenous people are missing out on an education. The awareness of the masses is needed to bridge the gap in education for these aboriginal children living in rural areas because the snowballing encounters brought about by advancement in society will be very hard to face by them and getting employed will be difficult when the time comes. This will definitely lead to the continuous grip of poverty and the malicious cycle for generations. In terms of education, aboriginal communities are still far behind compared to the mainstream society (Hasmah 2013; Hassan 1997, 2009; Nicholas 2006; Omar 2004).

In order to improve the quality of education, studies on the challenges faced by the Orang Asli is a must. First and foremost, the phenomenon of marginalization is one of the challenges that should be resolved. Marginalization usually exists in a few aspects which are in terms of basic facilities and employment chances. For instance, Orang Asli does not have sufficient water supply and electricity. The roads are full of holes, and some of them are made from timber and plus, they do not have vehicles. Road links to schools do not exist and to reach the nearest school, the one, and the only method is to use rivers because using lands is difficult. However, going to school by using longboats are very dangerous because during the wet season which falls between November and February, the rivers can turn very turbulent and this had sacrificed three lives on the Baram River in early January 2015 where two primary school children of SK Long Panai and their aunt died in a boat accident. In the rural area, most of the settlements still replaced electricity with sunlight, consumed natural water sources such as rainwater and the source of communication are river and dirt roads.

The mainstream education system is rejected by the Orang Asli in Malaysia (Mohd Roslan 2013; Nicholas 2006). What we need to overcome is the major challenge which is the various cultures and languages of the indigenous people. Having a family culture is a good and positive thing but this will result in the underestimation of the government's efforts by the indigenous people if they are too complied with the customs of their ancestors. For instance, the Department of Orang Asli Affairs (JHEOA) had run an educational program in 1995 with the objective of preparing indigenous children for entry into mainstream education but it happened to be a big failure because the educators at the central primary schools do not have any knowledge about the culture and tradition of the Orang Asli. The attitude of indifference in education had caused the failure to improve the quality of education among the Orang Asli. Due to not having any educational experience, their parents still remain ignorant and unconcerned about the importance of education for their children and the later generations.

It will come as a shock to the aboriginal children when they enter a school system which is a new environment for them where they have to meet new people with different kind of cultures and values for the first time in their entire life and it is believed that most of them are unable to adapt to it and eventually, the cases of dropping out from school increased. When an indigenous child is not used to being scolded or even beaten by their parents, they will start to be afraid and this can be attached to an example when they enter a school where such action will be committed against them. Furthermore, some of them are bullied and teased by the other student because they are not the same in terms of origin and culture. In order to prevent having to face all of these threats, these indigenous children will start to stay away from school or even choose to leave school and give up on education.

As we all known, a complete infrastructure facility is required to make school a good place for the indigenous children to study and this will surely build a perfect quality of education. However, the 
lack of infrastructure is a problem faced by the settlement and this is the barrier to improve the quality of education among them. Schools are unable to function well due to the lack of electricity and water facilities. Due to the limited roads that can be accessed, it is hard for educational resources such as textbooks, teaching and also learning materials to reach on time and this will delay the lecture course. On the other hand, location or in other words, geography, is another concern that we must focus on in order to ensure that the Orang Asli are allowed to expose to education. Studies after studies show that aboriginal people are isolated as they are scattered in remote areas. Orang Asli Development Department report showed $31.7 \%$ of indigenous villages located in remote areas, $61.45 \%$ in the suburbs and in the city of $1.38 \%$ (Norwaliza, 2015; Ramlee, 2015). The above data had demonstrated the reason why they are left out of the process of modernization and improvement in the quality of education failed. Eventually, indigenous children are left behind from their studies because they are located in a geographical position which is far inland.

News reported by the Star in 1997 had stated that 66 percent of the Orang Asli are illiterate and this is a serious problem that we must pay attention to. As stated by Martin Luther King, Jr, "nothing in all the world is more dangerous than sincere ignorance and conscientious stupidity" and thus we should play our part and make a continuous effort to let education as the key to improving the quality of life among the Orang Asli. Based on a study conducted, these Orang Asli should be a part of any national transformation program held by the government and marginalization should be stopped. This is often illustrated with the example of the Aboriginal Peoples Act 1954, which enables the Orang Asli community to be more competitive and be a part of the mainstream's national development. The assimilation of Orang Asli into the mainstream society helps to vanish the thoughts that they are treated as a group of insignificant people and will start to break the barrier, accept the latest education system and get out of poverty. They should be given more space and chances to voice out their thoughts and aspiration in the education system. Besides, indigenous children should also have the qualification and rights to get scholarships and allowance from the government to support their studies so that they are not isolated from the existing education system. For example, the Eighth Malaysia Plan (2001-2005) which emphasized national unity and harmony was implemented for the sake of indigenous children. The program held includes Textbook Aid Scheme (SBBT), Supplementary Food Plan (RMT) and Endowment Fund for Low-income Students (KWAPM).

Nevertheless, the school authority should run a campaign on a topic about the difference in the culture of the Orang Asli so that the other non-Orang Asli student will have the opportunity to access and learn about their unique culture and also religion. By having this method in success, they will embrace, learn and understand the cultural differences of their indigenous friends. Naturally, the non-Orang Asli student will start to respect the aboriginal student and join along with them in taking part in any activity. For instance, they will learn how to talk to people from different backgrounds. Having lots of friends in school will make the Orang Asli feel comfortable when they attend classes in school and thus, the rate of indigenous children dropping out of school declined. Embracing a "cultural difference" teaching method and considering the educational system with cultural differences is also an essential solution to resolve this problem. This is because with this kind of mainstream education system, the Orang Asli will not have any pressure and discrimination and isolation will not exist.

To counter with poor infrastructures, roads that link from their house to school should be seal with tar to make their journey to school more convenient and safer. Toilets and classrooms which are in a very terrible condition should be fixed as soon as possible because the environment for the study is very important in order to improve the quality of education among the Orang Asli. For example, proper desks, chairs, whiteboards, and other facilities should be provided in the classroom. The school building and students' and teachers' lodging should be furnished as it is needed. All of the statements above can be achieved by making the Tenth and Eleventh Malaysian Plan in smooth progress and we must bear in mind that the improvement in knowledge abilities and innovation can be accomplished by making school a better place to learn, study and absorb knowledge. Their school uniforms must be prepared for them in the right quantity and sizes for schooling just like the other ordinary student while textbooks and other supplies must arrive on time for them to attend their classes. Electricity and clean water supply should be provided and well developed. Moreover, to face the problem of remote and scattered settlement of the Orang Asli community where they are unable to access any kind of 
transport, The Resettlement Scheme and Integrated Development of Remote Villages Scheme has been planned.

\section{The Proposed Solution on Current Issues of Education of Orang Asli in Malaysia}

With some of the factors that have been discovered throughout those researches conducted by those brilliant professionals, there are some suggestions that could curb the problem that exists amongst the Orang Asli community in the education sector. One of the suggestions is to hold an awareness campaign towards the Orang Asli community. The reason why we need to hold it is to make sure that the whole Orang Asli community to be aware of the importance of education in improving the lifestyle of their people especially their children. This effort could ensure that the existing parents would become more responsible parents that care about their children's educational needs and attention well. At the same time, this initiative, just like the old English sayings, "hit two birds with one stone," could also eradicate the negative stigma about education in the minds of thousands of Orang Asli. Thus, this effort would make the current Orang Asli community, to make a warm approach towards accepting and prioritizing education in their daily lives.

Another solution that could solve this concerning problem is by tackling the children's accessibility to school problems. In order to tackle the accessibility problem, the responsible parties such as the government with the collaboration of Non-Government Organisation (NGO) at first need to start fixing and building the connectivity between the Orang Asli settlements and with their respective nearest school such as roads and bridges. With that being taken off, the government under the Ministry of Transportation should be able to provide adequate and free public transportation such as buses that could help the Orang Asli community especially the children to go to their school without haste nor time-consuming. Apart from solving the connectivity problem for the students, the next solution is would be building a hostel that is relatively close with or within the school. This effort could not only make it easier for the children to attend school but have erased their burden to travel far away from home to school that is very time-consuming. The students would be able to have quite good access to the infrastructures and facilities such as the public library and shops because of their stay in the hostel near or within the school. The result of these actions would be making sure that the children to have good accessibility and motivation to go to school and thriving in their academics.

In a nutshell, the Orang Asli are the minority communities that had been marginalized for decades and to achieve the aim to uplift poverty and quality of life them, education is the main key to success. Hard work should be taken by highlighting all development programs with respect to education quality requirements as their basic needs to improve the quality of education. Attention and concern should be given to them so that they will not feel neglected. Bearing in mind that action speaks louder than word and we, as a part of the Malaysian, should play our roles and work together hand-in-hand to help these people to face all kinds of challenges that encounter and make the world a better place for the Orang Asli.

\section{Conclusion}

In a conclusion, it is acknowledged that the Orang Asli community has problems in their progress in the education field which statistics have shown that the Orang Asli have one of the worse records in education compared with other major races such as Malays, the Chinese and even the Indians. Based on the studies conducted by the professionals, there are a lot of factors causing that specific problem. One of the factors is would be the awareness amongst the Orang Asli community towards education and another factor is would be the Orang Asli accessibility to their nearest education institution. To solve those problems, the responsible parties should make an awareness campaign about the importance of education towards the Orang Asli community and fix and establishing well accessibility for the Orang Asli to go to their nearest school. These solutions might be able to make sure that the progress of education for the Orang Asli community would not be in the status quo but become a giant 
leap that could push and benefit the people towards the more prosperous and progressive community in future time.

\section{References}

Abdul Wahab, N., Mustapha, R., \& Abu Taib, J. (2016). Membangun Modal Insan Orang Asli: Kajian Peranan Dan Penentuan Matlamat Pendidikan Dalam Kalangan Ibu Bapa Masyarakat Orang Asli Di Kuantan, Pahang. 12(3), 1-10.

Education: Definition of Education by Lexico. (n.d.). Retrieved from https://www.lexico.com/en/definition/education.

Kamarulzaman Kamaruddin \& Osman Jusoh (2008). Educational Policy and Opportunities of Orang Asli: A Study on Indigenous People in Malaysia. The Journal of Human Resource and Adult Learning. Vol. 4(1), 86-97.

Laila, O. N. A., Ishak, M. A. N. R., \& Khairudin, M. K. A. M. (2019, October 11). Pendidikan terima peruntukan tertinggi. Retrieved from https://www.bharian.com.my/berita/pendidikan/2019/10/616641/pendidikan-terima-peruntukantertinggi.

Marzuki, M., Mapjabil, J., \& Mohd Zainol, R. (2014). Mengupas Keciciran Pelajar Orang Asli Malaysia: Suatu Tinjauan Ke Dalam Isu Aksesibiliti Sekolah. 10(2), 189-196.

Mazzlida Mat Deli \& Ruhizan Mohamad Yasin (2016). Quality Education of Orang Asli in Malaysia. International Journal of Academic Research in Business and Social Sciences 2016. Vol. 6(11), 233-240.

Misnaton Rabahi, Hamidah Yusof \& Marinah Awang (2016). Leading Learning among the Indigenous Orang Asli Students: Setting the Scene. Malaysia Journal of Society and Space. Vol. $12(13), 120-134$.

Mohd Nor, M. M., \& Mohd Nor, M. N. (2018). Kesedaran Pendidikan Dan Minat Kerja Pelajar Orang Asli Suku Kaum Jakun Di Rompin, Pahang. 14(1), 72-86.

Mohd Roslan Rosnon (2016). Indigenous Education Policy in Malaysia: A Discussion of Normalization in Schooling. Journal of Education and Social Sciences. Vol. 4(June), 25-32.

Mohd Roslan Rosnon \& Sara Chinnasamy (2015). Indigenous Education Policy in Malaysia: Governmentality, Power/ Knowledge, and Discourse. The 3rd International Conference on Educational Research And Practice 2015 Proceedings. 20-31.

Stephen Then (2015). Orang Asli Issues: Access to Education Still Difficult. The Star Online Tuesday. 24 Mar 2015. Retrieved from:

https://www.thestar.com.my/lifestyle/family/features/2015/03/24/orang-asli-issuesaccess-to-education-still-difficult

Sumathi Renganathan, Dr. (2018). Teaching and engaging Orang Asli children. New Straits Times. 12 September 2018. Retrieved from: https://www.nst.com.my/opinion/letters/2018/09/410516/teaching-and-engagingorang-asli-children

Tarmiji Masron, Fujimaki Masami \& Norhasimah Ismail (2013). Orang Asli in Peninsular Malaysia: Population, Spatial Distribution, and Socio-Economic Condition. Ritsumei Journal of Social Sciences and Humanity. Vol. 6(7), 75-115.

Wan Hanafi, W. A., Ahmad, S., \& Ali, N. (2014). Faktor Budaya Dan Persekitaran Dalam Prestasi Pendidikan Anak Orang Asli Malaysia: Kajian Kes Di Kelantan. 10(5), 107-222. 